\title{
A Needs Analysis of Undergraduate Students of Communicative Skills: The Case of Tertiary Institutions in Ghana
}

\author{
Philip Arthur Gborsong, Joseph B. A. Afful, Wincharles Coker, Osei Yaw Akoto, \\ Rita Twumasi, Araba Baiden \\ Department of Communication Studies, University of Cape Coast, Cape Coast, Ghana \\ Email: pgborsong@yahoo.com
}

Received 6 June 2015; accepted 15 September 2015; published 18 September 2015

Copyright (C) 2015 by authors and Scientific Research Publishing Inc.

This work is licensed under the Creative Commons Attribution International License (CC BY).

http://creativecommons.org/licenses/by/4.0/

(c) (i) Open Access

\section{Abstract}

For over three decades now, research on undergraduate student pedagogy has shifted focus from an error analysis tradition to an emphasis on learner needs. As part of this shift, we examined the needs of students who offered Communicative Skills in an English-medium university in Ghana, and whether their needs were discipline-specific. Data were collected from two hundred and forty students and twenty lecturers, using a two-pronged sampling method. Major results showed a great need for grammar and writing skills among students, though they held that note taking and note making skills, outlining and skimming be expunged from the programme. The study also indicated that although teachers of Communicative Skills preferred a variationist approach, the reverse was the case among their students. Surprisingly, while students desired to be exposed to modern skills such as CV and Proposal writing, their instructors, on the other hand, were of the view that paragraph and essay development were not so useful. The study, thus, resonates with proclivities for further interventionist methods, specialist instructor (re)training and future research in undergraduate student writing.

\section{Keywords}

Needs Analysis, Communicative Skills, University Student, University of Cape Coast

\section{Introduction}

The scholarship on undergraduate student pedagogy has continually been faced with how best to improve upon learners' knowledge of communicative skills. In Ghana, as in most non-native contexts, the research landscape 
is occupied with error analysis, despite the demand for studies on needs analysis (Dako \& Forson, 1997; Dzameshie, 1997; Ababio, 2009). The extant literature is also replete with reductionist studies that examine such patterns of errors as spelling, tense and concord in Ghanaian university students’ writing (Yankson, 1994; Dako \& Forson, 1997). At the discourse level, it has been found that university students' essay prompts lack cohesion and has a weak thematic progression that often leads to flat paragraphs and undeveloped rhemes (Dako \& Forson, 1997; Appiah, 2002; Adika, 2003).

Given the foci of previous approaches, prominent among which is error analysis (e.g. Yankson, 1994; EduBuandoh, 1997; Appiah, 2002; Adika, 2003) to learner proficiency in Ghana, research into the unique needs of undergraduate students of Communicative Skills (otherwise known as General English or English for Academic Purposes (EAP) in foreign universities) is lacking (contra Dzameshie, 1997; Afful, 2007). As Seedhouse (1995) argues, "Needs analysis is rarely carried out in the General English classroom partly because of an erroneous belief that it is not possible to specify the needs of General English learners” (p. 59). Yet it is only when pedagogues and researchers identify students' learning difficulties that they can devise learner-centred and taskbased curricula (Berwick, 1989; Dudley-Evans \& John, 1998; Ababio, 2009). Needs analysis is, therefore, "the systematic collection and analysis of all relevant information necessary in the language learning requirements of the students within the context of the particular institutions involved in the learning situation” (Brown, 1995: p. 12). This current methodology is pivotal in learner pedagogy in Ghana because

Not until the teacher knows the needs of his/her students, he/she cannot plan a teachable lesson. The difficulty of the material to be covered, the amount of material to be learned must be determined by the teacher in relation to the abilities of the individuals to be taught or reached (Ababio, 2009: p. 2).

The argument becomes even more poignant given that the needs and orientations of students may vary with respect to such variables as their programmes of study, educational backgrounds and interests (Afful, 2007).

\section{Objective of the Study}

In view of the present approach, the study aimed at identifying the needs of Communicative Skills (CS) students of the University of Cape Coast (UCC), a public English medium university in Ghana established in 1962, in order to inform best teaching practices and maximise learners' understanding of topics treated during contact hours. For this reason, the study sought to meet the following specific objectives:

1) Examine whether the needs of CS students at UCC vary in respect of their programmes of study.

2) Compare the needs of first year CS students and continuing students.

3) Identify the views of CS lecturers concerning the needs of CS students.

\subsection{Research Design}

The study is a descriptive survey which enables researchers "to count; when they cannot count every one, it counts a representative sample and then makes inferences about the population as a whole” (Oppenheim, 1996: p. 8 cited in Ababio, 2009). A major advantage of the descriptive survey is its potential to provide researchers with a lot of information obtained from quite a large sample of individuals. The design is, therefore, useful in the present study because we aimed at ascertaining difficulties learners of CS encounter in order to surmount them through best interventionist programmes and revised course content.

\subsection{Sampling Method and Sample Size}

The total population of students that offered CS in the 2010/2011 academic year stood at 4083 (UCC Student Records and Management Information Section, 2010). Following Cohen, Manion and Morrison's (2000) typology for determining a sample size, we obtained an accessible population of 240 participants drawn from all the faculties. They comprised 120 first year CS students and 120 second, third and fourth year undergraduate students. Twenty lecturers who teach CS were selected out of a total of forty-five on the basis of their willingness to participate in the study.

The sample size was obtained, using a two-pronged sampling method. First, a simple random sampling was done in order to guarantee fairness of representativeness and the validity of results (Fraenkel \& Wallen, 2000; Cresswell, 2003). Participants were then selected based on stratified sampling technique. Thus, 30 students were selected from all the faculties and schools (i.e. School of Medical Sciences and School of Agriculture) of the 
university. Besides, the selection reflected gender representativeness, comprising 15 males and 15 females.

\subsection{Instrumentation}

Two sets of questionnaire (Appendix) were administered. The first and second sought to sample the views of CS students and CS lecturers respectively on the relevance, course components of the programme, and whether Communicative Skills should be taught based on students' programmes of study. These instruments were useful because they were amenable to statistical computations given the relatively large sample size of the study (Fraenkell \& Wallen, 2000). Further, the questionnaire has proven to be handy in needs analysis research (Richards, 2001; Ababio, 2009). The questionnaires comprised both closed-ended and open ended questions which were constructed on the Likert scale. The open-ended questions enabled respondents to express their views on issues which they hardly could convey in close-ended questions. A Cronbach's alpha reliability coefficient of 0.819 and 0.817 were obtained for the students' and lecturers' questionnaires respectively.

\subsection{Method of Data Analysis}

The mixed method of data analysis, quantitative and qualitative paradigms, was employed. As a form of methodological triangulation, this method of analysing data strengthens the validity of results (Cresswell, 2003). Inferential statistics was mainly used as a rigorous statistical package to reveal statistically significant differences or otherwise of elements under comparison. This method was supported by qualitative content analysis with the view to supply a detailed description of a point made.

\section{Results and Discussion}

This strand discusses among other things the background information, CS needs of first year and continuing students and CS lecturers' views on CS students' needs. Others include test for significant differences between first year and continuing students as well as responses on the relevance of Communicative Skills to university education and the job market.

\subsection{Background Information of Respondents}

Available evidence shows that out of a sample size of two hundred and sixty (made up of 240 students and 20 lecturers), 240 of them responded of which $91.7 \%$ were students while the remaining were lecturers. Of this number, the first year students accounted for 120 while the continuing students also totalled 120. Figure 1 depicts the gender distribution of the respondents.

The figure below shows a greater percentage of females (53\%) compared than males (43\%), thus indicating a difference of six percent. This difference was, however, not marginal to favour former over the latter in the analysis of the data. In addition, the educational background of respondents was also sought in order to understand the kind of educational training they had had. Figure 2 presents these results.
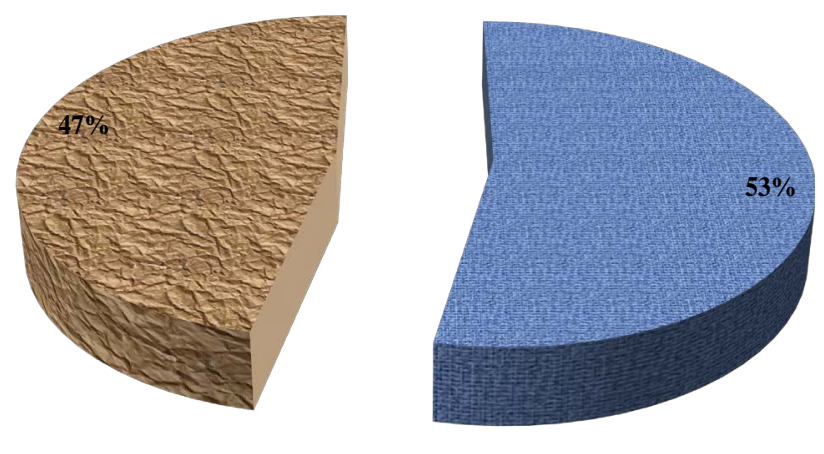

ธึ Male $\triangle$ Female

Figure 1. Gender distribution of student respondents. 


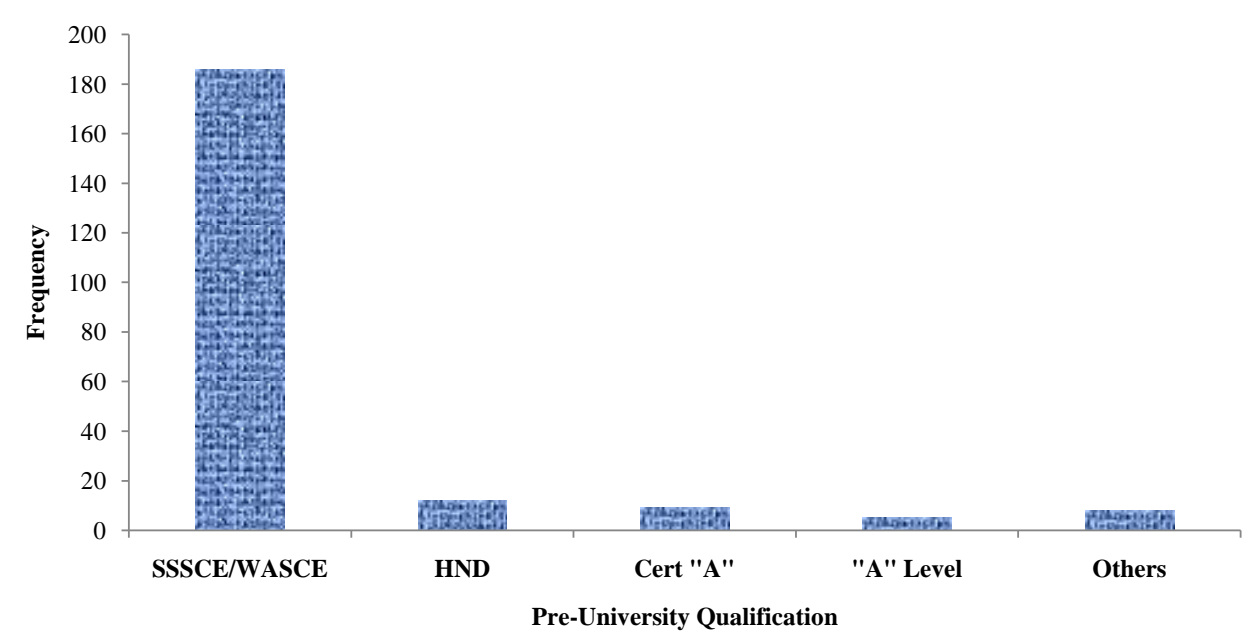

Figure 2. Pre-university qualifications of students.

It can be seen from Figure 2 that an overwhelming majority (84.5\%) of the students gained admissions into the University of Cape Coast (UCC) with the West African Examination Council's (WAEC) ${ }^{2}$ Senior Secondary School Certificate Examination (SSCE/WASSCE) while only 5.5\% entered UCC with Higher National Diploma (HND) in diverse fields of study.

Table 1 shows the frequency and percentage distribution of respondents vis-à-vis their faculties or schools. From the table, it is clear that more than forty percent of participants (40.5\%) offered education while less than fourteen percent of the respondents for both Business students (13.6\%) and Social Sciences (13.6\%). It should be noted that these percentage distributions comprise both first year and continuing students, and that the disparities resulted from irretrievable questionnaires though not anticipated.

\subsection{Students' Views of Their Needs in Communicative Skills}

Table 2 contains responses of first year (Level 100) student respondents on their Communicative Skills' needs. With a mean average value of 3.68, respondents strongly agreed that Communicative Skills (CS) is relevant to university students' education while 3.66 each of them indicated that CS is important to students because it enables them to correct their grammatical errors. Again, an overwhelming majority (94.6\%) of them were positive that CS equips students with a large vocabulary. This observation is reminiscent of Dzameshie's (1997) claim the Communicative Skills is indispensable to university education. The relevance of Communicative Skills obtained an overall mean value of 3.5. This value underscores the point that students really appreciated the importance of Communicative skills to their education.

In respect of which course components are most useful to CS students, $86.4 \%$ of the respondents agreed that concord, dangling modification and ambiguity are the most useful components of the Communicative Skills programme. This concession rated an average value of 3.33. With the lowest mean of $2.71,36.6 \%$ of the Level 100 students claimed that Basic Sentence Patterns is the most useful component of the programme. Indeed, the views of respondents are in tandem with Afful's (2007) conviction that CS students still believe that some components of the programme are no more useful. On the question of whether the teaching of the programme should be discipline-specific, it was observed that a 2.8 mean value was obtained. This means that respondents hardly agreed to this view, perhaps because they are less knowledgeable of its pedagogical significance.

The study also sought to investigate whether there exist any significant differences between the needs of Level 100 CS students and continuing (Level 200, 300 and 400) students. An independent sample t-test was run and the results are contained in Table 3.

From Table 3, it can be seen that only one significant result was realised on skills of note making and note taking such as skimming, scanning and outlining as the most useful components of the Communicative Skills programme. This means that first year students and continuing students had different views with regards to whether these skills are the most useful components of the programme. Generally, there were no statistically significant differences on the remaining 24 items. It can therefore, be concluded on the basis of the majority of 
Table 1. Distribution of students by faculties/schools.

\begin{tabular}{ccc}
\hline Faculty/school & Frequency & Percentage (\%) \\
\hline Education & 87 & 39.55 \\
Sciences (physical/biological/agric/medical) & 41 & 18.64 \\
Arts & 32 & 14.55 \\
Business & 30 & 13.64 \\
Social sciences & 30 & 13.64 \\
Total & $\mathbf{2 2 0}$ & $\mathbf{1 0 0 . 2}$ \\
\hline
\end{tabular}

respondents that there was no significant difference between the needs of first year students and continuing students in Communicative Skills.

Further, an ANOVA test was run to determine whether there exist any significant differences among students' Communicative Skills needs based on their faculties and schools. Table 4 contains the statistically significant results.

In all, the students across the various faculties and schools differed on only four (4) items out of the 25 constituting $16 \%$. For instance, there was no universal agreement among respondents from the various faculties and schools with regards to whether CS is important to students. They also expressed varied perceptions as to whether or not Communicative Skills is really meeting students' communicative needs. Again, the students from the various faculties and schools differed in their responses on whether or not reading and listening are the most important components of the programme. The lack of concession in students' responses shows that they tacitly do not support a programme-specific teaching approach.

\subsection{Lecturers' Views of Students' Needs in Communicative Skills}

Table 5 presents the views of lecturers of Communicative Skills. The table reveals that lecturers generally agreed that CS is a still a relevant programme of study. While the majority of lecturers (60.0\%) strongly agreed to the claim, $40.0 \%$ of them simply agreed. All of them (100.0\%) were also positive that CS is relevant to education. Interestingly, the lecturers, however, assigned an average rate (lowest) of 2.21 to the view that Communicative Skills equips students with a large vocabulary. Clearly, the low value means that the lecturer respondents did not highly appreciate the importance and relevance of Communicative Skills programme in the University.

With regards to whether such writing skills as paragraph and essay writing are the most useful components of the programme, a least mean value of 2.78 was obtained. This observation is rather worrying in the sense that it is generally believed that a writing course like CS should enhance learners' writing skills because "students usually produce many kinds of writing: notes during class sessions, written assignments, term papers...” (Biber \& Conrad, 2009: p. 1). Nonetheless, they seem to endorse the remediational concept of Communicative Skills that the primary objective of Communicative Skills is to correct students' grammatical errors. This is because their responses rated an average low value of 1.95 .

Further, unlike their students, the majority of the lecturers (70\%) agreed that Communicative Skills should be taught according to students' specific programmes of study. This view attracted an average value of 3.15. In other words, lecturers felt that different course contents and methods of delivery should be adopted in teaching students from such disciplines as Medical Sciences, Education or the Humanities. Such a need is crucial because contemporary research in student pedagogy now emphasises a variationist approach to teaching more than a generalist perspective (Dillon, 1991; MacDonald, 1994; Afful, 2005). As Afful (2007) argues, "Disciplines revolve around certain phenomena in the construction of knowledge” (p. 149).

\subsection{Personal Views of Students and Lecturers about Communicative Skills}

Below is catalogued some views expressed by both students and lecturers on the relevance of Communicative Skills to university education and the world of work. An interesting revelation from Table 6 indicates that both 
Table 2. Level 100 students’ communicative skills needs.

\begin{tabular}{|c|ccccc|c|c|c|c|}
\hline & \multicolumn{2}{c}{ SA } & A & & D & SD & M* S.D & Total \\
\cline { 2 - 7 } & Statements & No. $\%$ & No. & $\%$ & No. & $\%$ & No. & $\%$ & \\
\hline
\end{tabular}

Relevance of Communicative Skills:

Communicative Skills is important to students.

Communicative Skills is relevant to university students' education.

Communicative Skills enables students to correct their grammatical errors.

Communicative Skills assists students to write very good essays.

Communicative Skills equips students with a large vocabulary.

Communicative Skills sharpens students' speaking, writing, reading and listening skills.

Communicative Skills is really meeting students' communicative needs.

Course components:

Basic Sentence Pattern (SVO) is the most useful component of the Communicative Skills programme.

Skimming, Scanning and Outlining are the most useful components of the Communicative Skills programme.

Dangling Modification, Ambiguity and Concord

(Subject-Verb Agreement) are the most useful components of the Communicative Skills programme.

Paragraph Development and Easy Writing are the most useful components of the Communicative Skills programme.

The primary objective of Communicative Skills should be to correct students' grammatical errors.

The primary objective of Communicative Skills should be to develop students' speaking abilities.

Reading is the most important communicative skills

Writing is the most important communicative skills.

Speaking is the most important communicative skills.

Listening is the most important communicative skills.

Communicative Skills and Disciplinary Variation:

The teaching of Communicative Skills should focus on students' programmes of study.

The teaching of Communicative Skills based on specific discipline of students enables students to communicate effectively in their specific disciplines.

The teaching of Communicative Skills based on specific disciplines of student will make teaching and learning more efficient and productive.

Teaching Communicative Skills according to students' programme of study should emphasise grammatical correctness.

Teaching Communicative Skills according to students' programme of study should emphasise reading skills.

Teaching Communicative Skills according to students' programme of study should emphasise writing skills.

Outlining should be stamped out of the current Communicative Skills programme.

Skimming and Scanning should be stamped out of the current Communicative Skills programme.

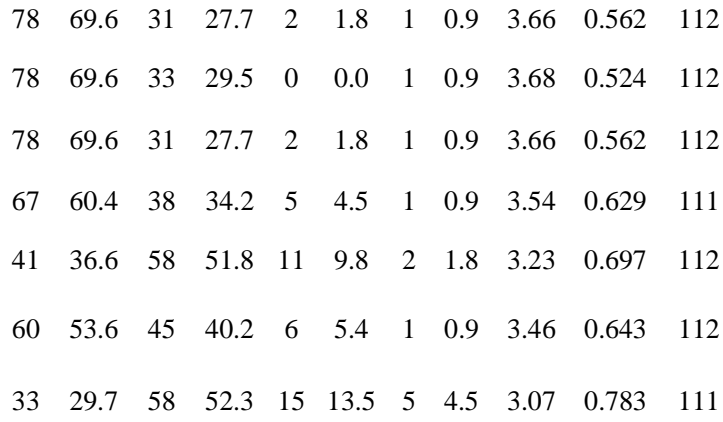

$\begin{array}{lllllllllll}20 & 17.9 & 51 & 45.5 & 29 & 25.9 & 12 & 10.7 & 2.71 & 0.889 & 112\end{array}$

$\begin{array}{lllllllllll}20 & 17.9 & 54 & 48.2 & 33 & 29.5 & 5 & 4.5 & 2.79 & 0.784 & 112\end{array}$

$\begin{array}{lllllllllll}55 & 49.5 & 41 & 36.9 & 12 & 10.8 & 3 & 2.7 & 3.33 & 0.778 & 111\end{array}$

$\begin{array}{lllllllllll}41 & 36.9 & 55 & 49.5 & 13 & 11.7 & 2 & 1.8 & 3.22 & 0.719 & 111\end{array}$

$\begin{array}{lllllllllll}50 & 45.9 & 43 & 39.4 & 11 & 10.1 & 5 & 4.6 & 3.27 & 0.824 & 109\end{array}$

$\begin{array}{lllllllllll}50 & 46.3 & 45 & 41.7 & 11 & 10.2 & 2 & 1.8 & 3.32 & 0.734 & 108\end{array}$

$\begin{array}{lllllllllll}30 & 29.4 & 39 & 38.2 & 27 & 26.5 & 6 & 5.9 & 2.91 & 0.891 & 102\end{array}$

$\begin{array}{lllllllllll}30 & 27.3 & 55 & 50.0 & 26 & 18.2 & 5 & 4.5 & 3.00 & 0.801 & 110\end{array}$

$\begin{array}{lllllllllll}41 & 37.6 & 49 & 45.0 & 14 & 12.8 & 5 & 4.6 & 3.16 & 0.818 & 109\end{array}$

$\begin{array}{lllllllllll}15 & 13.5 & 55 & 49.5 & 36 & 32.4 & 5 & 4.5 & 2.72 & 0.753 & 111\end{array}$

$\begin{array}{lllllllllll}31 & 27.9 & 38 & 34.2 & 27 & 24.3 & 15 & 13.5 & 2.77 & 0.411 & 111\end{array}$

$\begin{array}{lllllllllll}43 & 38.4 & 40 & 35.7 & 21 & 18.8 & 8 & 7.1 & 3.05 & 0.617 & 112\end{array}$

$\begin{array}{lllllllllll}45 & 40.2 & 47 & 42.0 & 15 & 13.4 & 5 & 4.5 & 3.18 & 0.830 & 112\end{array}$

$\begin{array}{lllllllllll}43 & 39.8 & 45 & 41.7 & 16 & 14.8 & 4 & 3.7 & 3.18 & 0.818 & 108\end{array}$

$\begin{array}{lllllllllll}29 & 26.4 & 61 & 55.5 & 14 & 12.7 & 6 & 5.5 & 3.03 & 0.784 & 110\end{array}$

$\begin{array}{lllllllllll}32 & 29.9 & 57 & 53.3 & 9 & 8.4 & 9 & 8.4 & 3.05 & 0.851 & 107\end{array}$

$\begin{array}{lllllllllll}26 & 23.2 & 19 & 17.0 & 28 & 25.0 & 39 & 34.8 & 2.29 & 0.423 & 112\end{array}$

$\begin{array}{lllllllllll}25 & 22.3 & 19 & 17.0 & 29 & 25.9 & 39 & 34.8 & 2.27 & 0.634 & 112\end{array}$

$\mathrm{M}^{*}$ is the mean, where $\mathrm{SD}=1 ; \mathrm{D}=2 ; \mathrm{A}=3 ; \mathrm{SA}=4$. 
Table 3. Test for significant differences between level 100 and continuing students' communicative skills needs.

\begin{tabular}{|c|c|c|c|}
\hline Statement & $\mathrm{t}$ & $p$ (2-tailed) & Results \\
\hline \multicolumn{4}{|l|}{ Relevance of Communicative Skills: } \\
\hline Communicative Skills is important to students. & -0.904 & 0.368 & ns \\
\hline Communicative Skills is relevant to university students' education. & -1.976 & 0.050 & ns \\
\hline Communicative Skills enables students to correct their grammatical errors. & -0.724 & 0.470 & ns \\
\hline Communicative Skills assists students to write very good essays. & 0.552 & 0.582 & ns \\
\hline Communicative Skills equips students with a large vocabulary. & -1.021 & 0.309 & ns \\
\hline Communicative Skills sharpens students’ speaking, writing, reading and listening skills. & 1.184 & 0.237 & ns \\
\hline Communicative Skills is really meeting students' communicative needs. & 1.807 & 0.073 & ns \\
\hline \multicolumn{4}{|l|}{ Course Components: } \\
\hline $\begin{array}{l}\text { Basic Sentence Pattern (SVO) is the most useful component of the } \\
\text { Communicative Skills programme. }\end{array}$ & 0.122 & 0.903 & ns \\
\hline $\begin{array}{l}\text { Skimming, Scanning and Outlining are the most useful components of the } \\
\text { Communicative Skills programme. }\end{array}$ & -2.100 & 0.017 & ss \\
\hline $\begin{array}{l}\text { Dangling Modification, Ambiguity and Concord (Subject-Verb Agreement) } \\
\text { are the most useful components of the Communicative Skills programme. }\end{array}$ & 0.297 & 0.767 & ns \\
\hline $\begin{array}{l}\text { Paragraph Development and Easy Writing are the most useful components of the } \\
\text { Communicative Skills programme. }\end{array}$ & 0.432 & 0.666 & ns \\
\hline $\begin{array}{l}\text { The primary objective of Communicative Skills should be to correct } \\
\text { students' grammatical errors. }\end{array}$ & 0.677 & 0.500 & ns \\
\hline $\begin{array}{l}\text { The primary objective of Communicative Skills should be to develop } \\
\text { students' speaking abilities. }\end{array}$ & 1.439 & 0.152 & ns \\
\hline Reading is the most important communicative skills & -1.191 & 0.236 & ns \\
\hline Writing is the most important communicative skills. & -1.841 & 0.068 & ns \\
\hline Speaking is the most important communicative skills. & -0.067 & 0.946 & ns \\
\hline Listening is the most important communicative skills. & -1.181 & 0.239 & ns \\
\hline \multicolumn{4}{|l|}{ Communicative Skills and Disciplinary Variation: } \\
\hline $\begin{array}{l}\text { The teaching of Communicative Skills should focus on } \\
\text { students' programmes of study. }\end{array}$ & -0.224 & 0.823 & ns \\
\hline $\begin{array}{l}\text { The teaching of Communicative Skills based on specific discipline of students enables } \\
\text { students to communicate effectively in their specific disciplines. }\end{array}$ & 0.336 & 0.738 & ns \\
\hline $\begin{array}{l}\text { The teaching of Communicative Skills based on specific disciplines of } \\
\text { student will make teaching and learning more efficient and productive. }\end{array}$ & -0.208 & 0.835 & ns \\
\hline $\begin{array}{l}\text { Teaching Communicative Skills according to students' } \\
\text { programme of study should emphasise grammatical correctness. }\end{array}$ & 0.427 & 0.670 & ns \\
\hline $\begin{array}{l}\text { Teaching Communicative Skills according to students' } \\
\text { programme of study should emphasise reading skills. }\end{array}$ & -0.527 & 0.599 & ns \\
\hline $\begin{array}{l}\text { Teaching Communicative Skills according to students' } \\
\text { programme of study should emphasise writing skills. }\end{array}$ & -0.695 & 0.488 & ns \\
\hline Outlining should be stamped out of the current Communicative Skills programme. & 0.622 & 0.532 & ns \\
\hline $\begin{array}{l}\text { Skimming and Scanning should be stamped out of the current } \\
\text { Communicative Skills programme. }\end{array}$ & 0.374 & 0.709 & ns \\
\hline
\end{tabular}

ss: Significant at $\alpha=0.025$, ns: Not significant at $\alpha=0.025$. 
students and lecturers claimed that self-esteem and analytical and communicative skills are the foremost relevance of the programme. According to them, Communicative Skills also enables an individual to face an interview panel and produce good letters and winnable curriculum vitaes as well as promote a research culture among students.

Finally, Table 7 presents the views of both students and lecturers about which aspects of the Communicative Skills programme should be excluded from or included in the content of the programme. Interestingly, all respondents (100\%) were of the view that such skills as CV and Proposal writing as well as such modern forms of presentation as power point be added into the content of the programme. A great majority (97.9\%) also felt that oral communication is an indispensable skill in communication. Meanwhile, $96.7 \%$ of the respondents strongly believed that the programme was overburdened with components such as note taking and note making.

\section{Implications}

This paper sought to examine the needs of students of Communicative Skills at the University of Cape Coast in Ghana. The study showed four major results. First, the research indicated that students have a positive attitude towards Communicative Skills because they agree the programme provides self-esteem, analytical and communicative skills such as good speaking and writing skills. They, however, believe that such components as note taking and note making, namely, outlining, skimming and scanning should be excluded from what they perceive to be an already overloaded course content. Second, contrary to the view that Communicative Skills students in universities in Ghana lack and abhor basic grammar (Dako \& Forson, 1997; Dzameshie, 1997; Kudom-Gyasi, Nartey \& Coker, 2011), results show that CS students claim that such grammar components as concord, ambiguity and misrelated constructions are very useful in writing.

Another major result reveals that students do not favour the teaching of Communicative Skills along the lines of their individual programmes of study, as there were no statistically significant differences in their responses. Perhaps, such an observation may have arisen out of their ignorance of the pedagogical significance of this approach. As well, both students and lecturers feel that the programme should be modified to include topics such as oral communication, CV and Proposal writing as well as modern forms of presentation such as power point.

Finally, the research elucidates that although lecturers undoubtedly claim that the programme is relevant to university education, they, however, feel that such writing skills as paragraph development and essay writing were not so useful. This reason was difficult to explain as it undermines the rationale of the programme. Again, unlike the students, an overwhelming majority of lecturers endorsed the variationist teaching approach.

There are practical and theoretical implications that resonate with this study. In the first place, the study points to an interventionist approach to the teaching of Communicative Skills. Although earlier proposed by Dzameshie (1997) and Afful (2007) among others, the present research brings novel insights into the urgent need to modify the programme content in order to meet current exigencies so far as learner needs are concerned. Further, the research has implications for teacher retraining and/or specialist training. Such a move is crucial so that new modes of teaching will be assimilated and attitudes that stifle the progress of the programme will duly be minimised. Third, the research holds implications for the degree to which disciplinary variation can thrive in a nonAfrican context such as Ghana. Given the paucity of expertise coupled with lean logistics, it is doubtful whether lecturers can optimally operationalise this concept.

Table 4. Test for significant differences in communicative skills needs based on faculty/school.

\begin{tabular}{|c|c|c|c|}
\hline Statement & $\mathrm{F}$ & $p$ (2-tailed) & Results \\
\hline \multicolumn{4}{|l|}{ Relevance of Communicative Skills: } \\
\hline Communicative Skills is important to students. & 6.073 & 0.000 & ss \\
\hline Communicative Skills is really meeting students' communicative needs. & 3.269 & 0.013 & ss \\
\hline \multicolumn{4}{|l|}{ Course Components: } \\
\hline Reading is the most important communicative skills. & 2.431 & 0.022 & ss \\
\hline Listening is the most important communicative skills. & 2.541 & 0.020 & ss \\
\hline
\end{tabular}

ss: Significant at $\alpha=0.025$, ns: Not significant at $\alpha=0.025$. 
Table 5. Lecturers' views of students' needs in communicative skills.

\begin{tabular}{|c|c|c|c|c|c|c|c|c|c|c|c|}
\hline \multirow{2}{*}{ Statements } & \multicolumn{2}{|c|}{ SA } & \multicolumn{2}{|c|}{ A } & \multicolumn{2}{|c|}{$\mathbf{D}$} & \multicolumn{2}{|c|}{ SD } & \multirow{2}{*}{\multicolumn{2}{|c|}{ M* S.D }} & \multirow{2}{*}{ Total } \\
\hline & No. & $\%$ & No. & $\%$ & No. & $\%$ & No. & $\%$ & & & \\
\hline \multicolumn{12}{|l|}{ Relevance of Communicative Skills: } \\
\hline Communicative Skills is important to students. & 12 & 60.0 & 8 & 40.0 & 0 & 0.0 & 0 & 0.0 & 3.60 & 0.503 & 20 \\
\hline $\begin{array}{c}\text { Communicative Skills is relevant to university } \\
\text { students' education. }\end{array}$ & 10 & 50.0 & 10 & 50.0 & 0 & 0.0 & 0 & 0.0 & 3.50 & 0.513 & 20 \\
\hline $\begin{array}{l}\text { Communicative Skills enables students to correct } \\
\text { their grammatical errors. }\end{array}$ & 5 & 25.0 & 7 & 35.0 & 8 & 40.0 & 0 & 0.0 & 2.85 & 0.813 & 20 \\
\hline $\begin{array}{c}\text { Communicative Skills assists students to write } \\
\text { very good essays. }\end{array}$ & 6 & 30.0 & 12 & 60.0 & 2 & 10.0 & 0 & 0.0 & 3.20 & 0.616 & 20 \\
\hline $\begin{array}{l}\text { Communicative Skills equips students with a large } \\
\text { vocabulary. }\end{array}$ & 3 & 15.8 & 3 & 15.8 & 8 & 42.1 & 5 & 26.3 & 2.21 & 0.431 & 19 \\
\hline $\begin{array}{l}\text { Communicative Skills sharpens students' speaking, } \\
\text { writing, reading and listening skills. }\end{array}$ & 5 & 27.8 & 7 & 38.9 & 6 & 33.3 & 0 & 0.0 & 2.94 & 0.802 & 18 \\
\hline $\begin{array}{l}\text { Communicative Skills is really meeting students' } \\
\text { communicative needs. }\end{array}$ & 0 & 0.0 & 6 & 30.0 & 14 & 70.0 & 0 & 0.0 & 2.30 & 0.470 & 20 \\
\hline
\end{tabular}

\section{Course Components:}

Basic Sentence Pattern (SVO) is the most useful component of the Communicative Skills programme.

Skimming, Scanning and Outlining are the most useful components of the Communicative Skills programme.

Dangling Modification, Ambiguity and Concord

(Subject-Verb Agreement) are the most useful components of the Communicative Skills programme.

Paragraph Development and Easy Writing are the most useful components of the Communicative Skills programme.

The primary objective of Communicative Skills should be to correct students' grammatical errors.

The primary objective of Communicative Skills should be to develop students' speaking abilities.

Reading is the most important communicative skills Writing is the most important communicative skills.

Speaking is the most important communicative skills.

Listening is the most important communicative skills.

Communicative Skills and Disciplinary Variation:

The teaching of Communicative Skills should focus on students' programmes of study.

The teaching of Communicative Skills based on specific discipline of students enables students to communicate effectively in their specific disciplines.

The teaching of Communicative Skills based on specific

disciplines of student will make teaching and learning more efficient and productive.

Teaching Communicative Skills according to students' programme of study should emphasise grammatical correctness.

Teaching Communicative Skills according to students' programme of study should emphasise reading skills.

Teaching Communicative Skills according to students' programme of study should emphasise writing skills.

Outlining should be stamped out of the current Communicative Skills programme.

7502423Skimming and Scanning should be stamped out of the current Communicative Skills programme.

\begin{tabular}{|c|c|c|c|c|c|c|c|c|c|}
\hline 0 & 0.0 & 2 & 11.1 & 15 & 83.3 & 1 & 5.6 & 2.06 & 0.416 \\
\hline 0 & 0.0 & 5 & 27.8 & 13 & 72.2 & 0 & 0.0 & 2.28 & 0.461 \\
\hline 2 & 11.1 & 10 & 55.6 & 6 & 33.3 & 0 & 0.0 & 2.78 & 0.647 \\
\hline 4 & 20.0 & 8 & 40.0 & 8 & 40.0 & 0 & 0.0 & 2.80 & 0.768 \\
\hline 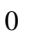 & 0.0 & 2 & 10.0 & 15 & 75.0 & 3 & 15.0 & 1.95 & 0.510 \\
\hline 0 & 0.0 & 2 & 10.0 & 16 & 80.0 & & 10.0 & 2.00 & 0.459 \\
\hline 0 & 0.0 & 5 & 25.0 & 15 & 75.0 & 0 & 0.0 & 2.25 & 0.444 \\
\hline 2 & 11.2 & 8 & 44.4 & 8 & 44.4 & 0 & 0.0 & 2.67 & 0.686 \\
\hline 2 & 11.2 & 2 & 11.2 & 14 & 77.6 & 0 & 0.0 & 2.33 & 0.686 \\
\hline 3 & 15.0 & 1 & 5.0 & 11 & 55.0 & 5 & 25.0 & 2.10 & 0.960 \\
\hline$y$ & 45.0 & 5 & 25.0 & 6 & 30.0 & 0 & 0.0 & 3.15 & 0.875 \\
\hline 4 & 20.0 & 7 & 35.0 & 9 & 45.0 & 0 & 0.0 & 2.75 & 0.786 \\
\hline 4 & 22.2 & 5 & 27.8 & 9 & 50.0 & 0 & 0.0 & 2.72 & 0.826 \\
\hline 2 & 11.1 & 4 & 22.2 & 12 & 66.7 & 0 & 0.0 & 2.44 & 0.705 \\
\hline 1 & 5.6 & 4 & 22.2 & 13 & 72.2 & 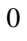 & 0.0 & 2.33 & 0.594 \\
\hline 2 & 11.1 & 5 & 27.8 & 11 & 61.1 & 0 & 0.0 & 2.50 & 0.707 \\
\hline 1 & 5.0 & 6 & 30.0 & 12 & 60.0 & 1 & 5.0 & 2.35 & 0.671 \\
\hline 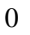 & 0.0 & 8 & 40.0 & 10 & 50.0 & 2 & 10.0 & 2.30 & 0.657 \\
\hline
\end{tabular}

$\mathrm{M}^{*}$ is the mean, where $\mathrm{SD}=1 ; \mathrm{D}=2 ; \mathrm{A}=3 ; \mathrm{SA}=4$. 
Table 6. Views on the relevance of communicative skills to education and job market.

\begin{tabular}{|c|c|c|c|c|}
\hline \multirow{2}{*}{ Views } & \multirow{2}{*}{$\begin{array}{l}\text { Students } \\
(\mathrm{n}=\mathbf{2 2 0})\end{array}$} & \multirow{2}{*}{$\begin{array}{l}\text { Lecturers } \\
\qquad(\mathrm{n}=\mathbf{2 0})\end{array}$} & \multicolumn{2}{|c|}{ Total } \\
\hline & & & $(\mathrm{N}=240)$ & $\%$ \\
\hline Helps to have good self-esteem. & 220 & 20 & 240 & 100.0 \\
\hline Helps to analyse questions before answering. & 220 & 18 & 238 & 99.2 \\
\hline Helps to face interview panel. & 220 & 15 & 235 & 97.9 \\
\hline Helps to prepare good letters and CVs. & 215 & 10 & 225 & 93.8 \\
\hline Helps to enhance educational research. & 200 & 18 & 218 & 90.8 \\
\hline Others & 198 & 10 & 208 & 86.7 \\
\hline
\end{tabular}

Table 7. Perceptions about course components of communicative skills.

\begin{tabular}{|c|c|c|c|c|}
\hline \multirow{2}{*}{ Views } & \multirow{2}{*}{$\begin{array}{l}\text { Students } \\
(n=220)\end{array}$} & \multirow{2}{*}{$\begin{array}{l}\text { Lecturers } \\
\qquad(\mathrm{n}=20)\end{array}$} & \multicolumn{2}{|c|}{ Total } \\
\hline & & & $(N=240)$ & $\%$ \\
\hline CV and proposal writing. & 220 & 20 & 240 & 100.0 \\
\hline Modern forms of presentations (e.g. power-point presentations). & 220 & 20 & 240 & 100.0 \\
\hline Oral communication added. & 215 & 20 & 235 & 97.9 \\
\hline Over-loaded component (e.g. Outlining, Skimming and Scanning removed). & 220 & 12 & 232 & 96.7 \\
\hline Others & 178 & 10 & 188 & 78.3 \\
\hline
\end{tabular}

\section{Conclusion}

In conclusion, further research can replicate this study on other university campuses preferably in Ghana so that we could ascertain how far the finding of this research applies to other universities. Future endeavours could also consider whether such factors as age, gender, students' educational and socio-economic backgrounds impact significantly on learner needs.

\section{Notes}

1) Special thanks go to all students and lecturers at the University of Cape Coast, Ghana who participated in this research We are most grateful to the management and staff of the Department of Communication Studies, University of Cape Coast for funding of the project and Mr. Francis Agude of Data Processing and Quality Assurance of university of Cape Coast for his brilliant technical support in the statistical computation of the study.

2) The West African Examinations Council (WAEC) is the mandatory examining governing body that conducts examinations for candidates at the junior and senior high schools for such countries as Ghana, Nigeria and Sierra Leone.

\section{References}

Ababio, B. T. (2009). Identifying Students’ Background and Needs for Effective Teaching at the University of Cape Coast. Drumspeak: International Journal of Research in the Humanities, 2, 1-27.

Adika, G. S. K. (2003). A Theme-Structure Approach to Evaluating Aspects of University Students' Expository Texts. In E. K. Osam, \& G. S. K. Adika (Eds.), Legon Journal of the Humanities, 14, 55-78.

Afful, J. B. A. (2005). A Rhetorical Analysis of Examination Essays in Three Disciplines: The Case of Ghanaian Undergraduate Students. Unpublished PhD Thesis, National University of Singapore.

Afful, J. B. A. (2007). Academic Literacy and Communicative Skills in the Ghanaian University: A Proposal. Nebula, 4 , 141-159.

Appiah, F. B. (2002). A Study of Paragraph Development in First Year University Students’ Communicative Skills’ Essays. Unpublished MPhil Thesis, Ghana: University of Cape Coast.

Berwick, R. (1989). Needs Assessment in Language Programming: From Theory to Practice. In R. K. Johnson (Ed.), The Second Language Curriculum (pp. 48-62). Cambridge: Cambridge University Press.

http://dx.doi.org/10.1017/CBO9781139524520.006 
Biber, D., \& Conrad, S. (2009). Register, Genre and Style. Cambridge: Cambridge University Press. http://dx.doi.org/10.1017/CBO9780511814358

Brown, J. D. (1995). The Elements of Language Curriculum: A Systematic Approach to Program Development. Boston, MA: Heinle \& Heinle.

Cohen, L., Manion, L., \& Morrison, L. (2000). Research Methods in Education. London \& New York: Routledge. http://dx.doi.org/10.4324/9780203224342

Cresswell, J. W. (2003). Research Design: Qualitative and Quantitative and Mixed Approaches (2nd ed.). Thousand Oaks, CA: Sage.

Dako, K., \& Forson, E. B. (1997). The Ghanaian University Students’ Knowledge of Grammar. In M. E. Kropp Dakubu (Ed.), English in Ghana (pp. 53-68). Accra: Ghana Universities Press.

Dillon, G. (1991). Contending Rhetorics: Writing in Academic Disciplines. Bloomingdale: Indiana University Press.

Dudley-Evans, T., \& John, M. (1998). Developments in ESP: A Multi-Disciplinary Approach. Cambridge: Cambridge University Press.

Dzameshie, A. (1997). Towards a Communicative Approach to Teaching English as a Second Language in Ghana. In M. E. Kropp Dakubu (Ed.), English in Ghana (pp. 173-194). Accra: Ghana Universities Press.

Edu-Buandoh, D. F. (1997). A Preliminary Report on the Study of Error Patterns in the Written Essays of Senior Secondary Students. In M. E. Kropp Dakubu (Ed.), English in Ghana (pp. 195-210). Accra: Ghana Universities Press.

Fraenkel, J. R., \& Wallen, N. E. (2000). How to Design \& Evaluate Research in Education (4th ed.). New York: McGraw High School.

Gyasi Kodom, W., Nartety, T. A., \& Coker, W. (2011). So, Is This Why We Fail? An Analysis of Communicative Skills Students' Knowledge of Parts of Speech. Faculty of Arts Lecture Series, Ghana: University of Cape Coast.

MacDonald, S. P. (1994). Professional Academic Writing in the Humanities and Social Sciences. Carbondale: Southern Illinois University Press.

Richards, J. (2001). Curriculum Developments in Language Teaching. Cambridge: Cambridge University Press. http://dx.doi.org/10.1017/CBO9780511667220

Seedhouse, P. (1995). Needs Analysis and the General English Classroom. ELT Journal, 49, 59-65.

Yankson, K. E. (1994). Better English through Concord for West African Students. Uruowulu-Obosi: Pacific College Press. 


\section{Appendix}

\section{Students' Communicative Skills Needs}

Read the statements in the table below and respond to the statements appropriately. It is to find out the relevance of the communicative skills programme to you as a student.

1) State your level............................. e.g. level 100

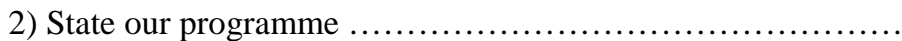

3) State the semester.

Read the following statements carefully, and put a tick $/ \sqrt{ } /$ in the margin provided under the headings.

SA = Strongly Agree, $\mathrm{A}=$ Agree, $\mathrm{D}=$ Disagree and SD = Strongly Disagree .

\section{Statements}

Communicative Skills is important to students.

Communicative Skills is relevant to university students' education.

Communicative Skills enables students to correct their grammatical errors.

Communicative Skills assists students to write very good essays.

Communicative Skills equips students with a large vocabulary.

Communicative Skills sharpens students' speaking, writing, reading and listening skills.

Communicative Skills is really meeting students' communicative needs.

\section{Course Components:}

Basic Sentence Pattern (SVO) is the most useful component of the Communicative Skills programme.

Skimming, Scanning and Outlining are the most useful components of the Communicative Skills programme.

Dangling Modification, Ambiguity and Concord (Subject-Verb Agreement) are the most useful components of the Communicative Skills programme.

Paragraph Development and Easy Writing are the most useful components of the Communicative Skills programme.

The primary objective of Communicative Skills should be to correct students' grammatical errors.

The primary objective of Communicative Skills should be to develop students' speaking abilities.

Reading is the most important communicative skills.

Writing is the most important communicative skills.

Speaking is the most important communicative skills.

Listening is the most important communicative skills.

\section{Communicative Skills and Disciplinary Variation:}

The teaching of Communicative Skills should focus on students' programmes of study.

The teaching of Communicative Skills based on specific discipline of students enables students to communicate effectively in their specific disciplines.

The teaching of Communicative Skills based on specific disciplines of student will make teaching and learning more efficient and productive.

Teaching Communicative Skills according to students' programme of study should emphasise grammatical correctness.

Teaching Communicative Skills according to students’ programme of study should emphasise reading skills.

Teaching Communicative Skills according to students’ programme of study should emphasise writing skills.

Outlining should be stamped out of the current Communicative Skills programme.

Skimming and Scanning should be stamped out of the current Communicative Skills programme. 